University of Nebraska - Lincoln

DigitalCommons@University of Nebraska - Lincoln

Textile Society of America Symposium

Proceedings

$10-2020$

\title{
Of Prophets, Caterpillars, and Silver: Job and the Origin-story of Sericulture in the Early Modern Islamic World
}

Nader Sayadi

Follow this and additional works at: https://digitalcommons.unl.edu/tsaconf

Part of the Art and Materials Conservation Commons, Art Practice Commons, Fashion Design Commons, Fiber, Textile, and Weaving Arts Commons, Fine Arts Commons, and the Museum Studies Commons

This Article is brought to you for free and open access by the Textile Society of America at DigitalCommons@University of Nebraska - Lincoln. It has been accepted for inclusion in Textile Society of America Symposium Proceedings by an authorized administrator of DigitalCommons@University of Nebraska - Lincoln. 


\title{
Of Prophets, Caterpillars, and Silver: Job and the Origin-story of Sericulture in the Early Modern Islamic World
}

\author{
Nader Sayadi \\ nsayadi@utexas.edu
}

Like most pre-modern guilds and crafts worldwide, the silk craft had origin-stories and patron saints to provide its practitioners with a "historical" background and institutional heredity. In the early modern Islamic world, specifically during the Safavid era, a rare seventeenth-century treatise on silk-weaving written in Persian weaves together the origin-story of sericulture and the Abrahamic narrative of Job (Ayyoub). Various renditions of the story of Job in several sources such as the Bible, Qur'an, and The Story of Prophets (Qisas al-Anbiya') literature share a core consisting of four stages of Job's life: prosperity, hardship, affliction, and restoration. Although the silk-weaving treatise includes these four stages, its rendition of the story is unique in associating Job with silkworms and a white mulberry tree- two aspects of the story nowhere else attested. This seemingly insignificant alteration to the story of Job sheds light on the increasing prestige of weavers in Safavid Iran and the far-reaching consequences of the flow of silver from the New World to the early modern Islamic world. This paper establishes the context for this rare silk-weaving treatise by a diachronic investigation of the story of Job from the Book of Job to the treatise's contemporary copies of the Story of Prophets. It demonstrates how far the author of the treatise had gone in inserting silkworms and a mulberry tree into a traditional story of Job. The paper consequently argues that Job was a particularly suitable Abrahamic prophet to be associated with the silk industry due to worms' involvement in the traditional story of Job. Finally, it argues that a combination of a robust Safavid silk industry and European tradesupported by American silver - during the sixteenth century contributed to a rise in silk-workers' social status in Safavid Iran. As a result, the story of Job was embroidered with a section discussing sericulture to confirm the socio-religious status of the silk craft.

\section{A Safavid treatise on silk-weaving}

Textile crafts, guilds, and artisans were integral parts of the medieval and early modern Islamic world. The quantity and quality of Islamic textiles in collections worldwide testify to their significance. Textiles were essential for urban development, as they structured the social relationships that formed the cities. Although numerous historical sources on cities in the Islamic world inform us about textile centers and their products, they tend not to discuss socio-cultural interactions between textile weavers and their societies. As a result, the social dynamics of early modern textile crafts in the Islamic world remain understudied.

Among a few known early modern Islamic textual sources, the seventeenth-century 'Treatise on Silk-weaving and Grasping the Grip of the Shuttle' sheds light on silk-weavers' place in Iranian society during the late sixteenth and early seventeenth centuries. ${ }^{1}$ Completed by an unknown author on October 18, 1606, this approximately 2700-word treatise written in Persian consists of

\footnotetext{
1 "Risāli-yi Sha 'rbāfĩ va Giriftan-i Qabzi-yi Mākū," The Iranian Parliament Libraries, Museum, and Archives. For an edition of the treatise, see: Mehran Afshari, Sì Futuwwat-nāmi-yi Dīgar, Sì Risāli-yi Nāshinākhti dar Futuwwat va Pīshivarī va Qalandarī (Tehran: Chishmi, 1391/2012), 187-206.
} 
discussions associating sericulture and silk-weaving with celestial figures, patron saints (or pirs), and contemporary virtuoso in the craft.

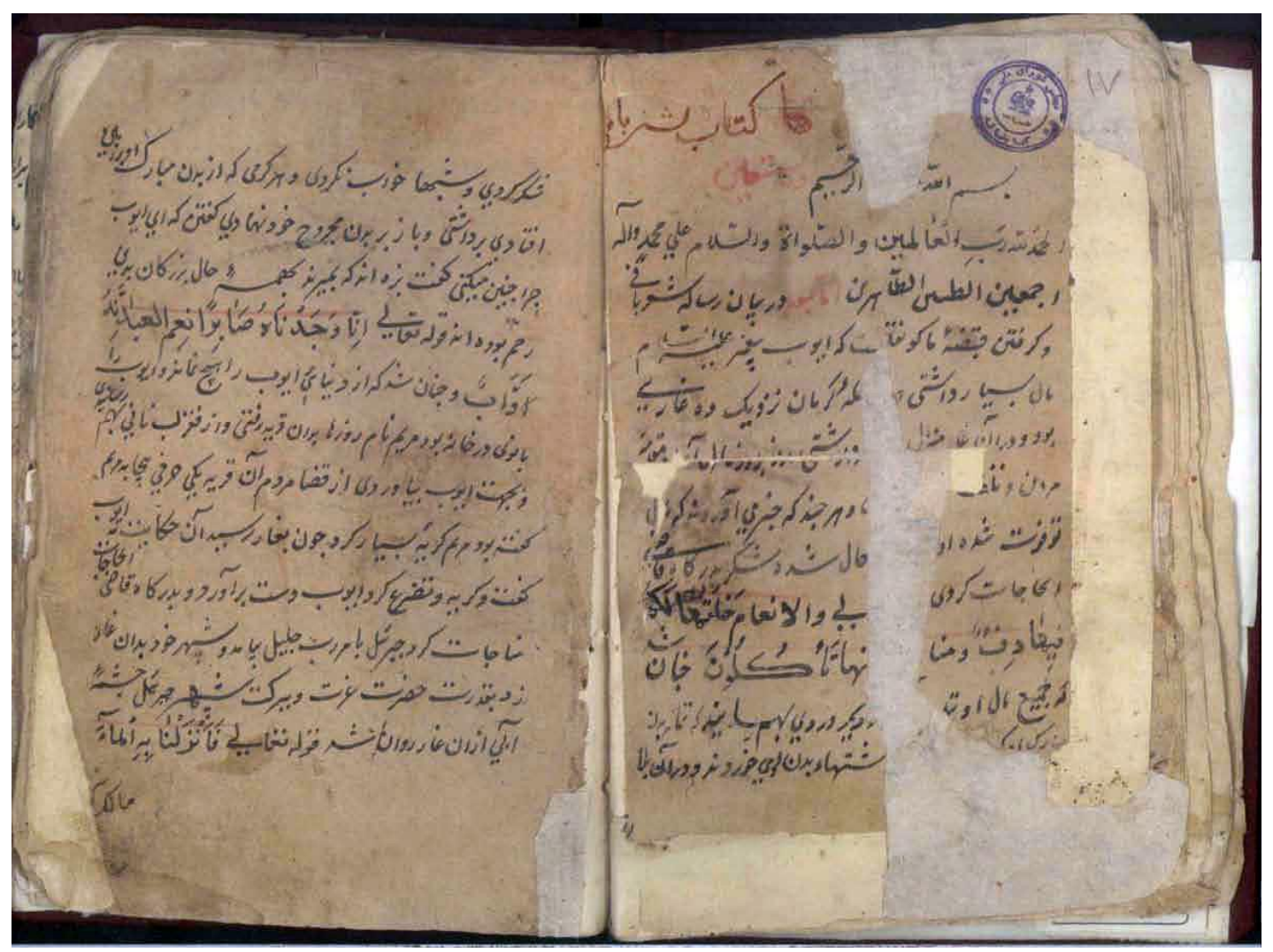

The Treatise on Silk-weaving and Grasping the Grip of the Shuttle (Risāli-yi Sha 'rbāfi va Giriftan-i Qabzi-yi Māku), The Library, Museum and Documentation Center of I.R.Iran Parliament, 8622/2

This treatise is a rare example of a genre of treatises and manuals, collectively known as the futuwwatnāma, which were dedicated to crafts. This genre linked the futuwwa- the mature human quality associated with Sufism - with social groups in the form of brotherhood involved in the Islamic world's crafts and trade. Futuwwatnämas provided practitioners within a given craft with moral lessons by discussing various mystical and religious topics. These texts were read by or to artisans to help them locate themselves within the universe of pious professions in Islamic societies. ${ }^{2}$ As is common practice in futuwwatnämas, the silk-weaving treatise included

\footnotetext{
${ }^{2}$ Khachik Gevorgyan, "Futuwwa Varieties and the Futuwwat-nama Literature: An Attempt to Classify Futuwwa and Persian Futuwwat-namas," British Journal of Middle Eastern Studies 40, no.1 (2013), 7; Willem Floor, "The Guilds in Iran - an Overview from the Earliest Beginnings till 1972," in Zeitschrift der Deutschen Morgenländischen Gesellschaft 125, no. 1 (1975), 106; Willem Floor, "Fotovvat va Asnaf." Review of Chāhārdah Riāli dar Bāb-i Futuwwat va Asnāf, ed. Mehran Afshari and Mehdi Madayeni. Iranian Studies 37, no. 2 (2004): 366-367; Claude Cahen and Franz Taeschner, "Futuwwa," in the Encyclopaedia of Islam, vol. 2 (C-G), ed. B. Lewis, Ch. Pellat, and J. Schacht (Leiden: Brill, 1991), 961; Mehran Afshari and Mahdi Madayeni, Chāhārdah Riāli dar Bāb-i Futuwwat va Asnäf (Tehran: Chishmi, 1385/2006), 12; Najm al-Din Zarkoub, "Futuwwatnama," in Rasā'l-i Javānmardān, Mushtamil bar Haft Futuvvatnāmi, ed. Morteza Sarraf (Tehran and Paris: Departement d'Iranologie de L'Institut Franco-Iranien de Recherche, Mo in Publishing House, and Librairie d'Amerique et d'Orient Adrien-Maisonneuve, 1352/1973), 167-218; Mehdi Keyvani, Artisans and Guild Life in the Later Safavid Period, Constructions to the Social-economic History of Persia (Berlin: Klaus Schwarz, 1982), 206.
} 
an origin-story of silk. Unlike Roman or Chinese origin-stories of silk, the treatise attributes the founding of sericulture and silk-weaving to Job, a prominent prophet in the Abrahamic religious narratives, and a traditional model of patient endurance (or hypomone). ${ }^{3}$

\section{A traditional story of Job and its four main stages}

The story of Job, as usually told in Abrahamic religious texts generally consists of these four main stages. First, the story introduces Job as a prosperous individual - with wealth aplenty and a large and happy family — who is faithful to God. Second, Satan (Iblīs) suggests to God that Job would not remain faithful if he fell into hardship. God consequently allowed Satan to take anything from Job but his life to prove Satan wrong. Satan takes Job's wealth, then his family, then his health. Everyone abandons and rejects Job but his wife. Job suffers immensely from the unexpected losses for years. Third, during the time of affliction, Job discusses his faith and his doubts concerning God's will and justice in conversations with his wife, friends, strangers, Satan, and God. Satan and a few individuals unsuccessfully provoke Job to give up his faith in God. Job remains patient and faithful. Finally, God rewards Job by restoring his health, family, and wealth in return for Job's persistence in keeping his faith. ${ }^{4}$ These four stages comprise what this study calls a traditional story of Job. The version of the story of Job recounted in the 'Treatise on Silk-weaving and Grasping the Grip of the Shuttle' preserves this essential core of the story.

The traditional story of Job developed in Jewish, Christian, and Islamic traditions. Although the story's main structure remains the same, details and emphases differ from source to source. For example, 38 out of 42 chapters of the Book of Job in the Hebrew Bible discuss multiple topics, such as theodicy in the story's third stage..$^{5}$ In contrast, sources in Islamic traditions often concentrate on Job's affliction and restoration, the second and fourth stages, respectively. Job, or Ayyub in Islamic traditions, is only mentioned eight times in four verses in the Qur'an; half of them narrate the restoration of Job.

Although the Qur'an's mentions of Job are significantly shorter than pre-Islamic religious texts, they still expand on the story. In particular, the Qur'an associates Job's miraculous healing with a pond, which is absent in pre-Islamic narratives. In the Surah Sad, it is noted that God ordered Job to stamp the ground with his foot at the beginning of Job's restoration. As a result, a miraculous spring appeared to provide Job with sacred water to bathe in and drink from to recover his body. ${ }^{6}$ This detail does not appear in the story of Job's pre-Islamic narratives.

\footnotetext{
${ }^{3}$ Carol A. Newsom, "Plural Versions and the Challenge of Narrative Coherence in the Story of Job," in The Oxford Handbook of Biblical Narrative, ed. Danna Nolan Fewell (New York: Oxford University Press: 2016), 238; Claudio Zanier, Miti e culti della seta. Dalla Cina all'Europa (Padova: Universita` di Padova, CLEUP, 2019); Claudio Zanier, "Silk Cultivation in Italy, Medieval and Early Modern," Journal of Medieval Worlds (Winter 2019), 41-44.

${ }^{4}$ Roberto Tottoli, Biblical Prophets in the Qur' an and Muslim Literature (New York: Routldge, 2002), $42-44$.

5 The Book of Job: 1: 1-2 (Job's genealogy and ancestry); 1: 3-5 (Job’s prosperity); 1: 6-22 and 2: 1-10 (Job's affliction Satan taking away Job's prosperity, family, and health with God's permission); 2:11 and :3-27 (Job's discussions with others (other people, his wife, Satan, God) regarding his difficulties + Satan's temptations); 28-41 and 42:1-8 (Interpretations and discussions around Job and the idea of patience); 42: 9-17 (Gabriel, the spring(s), and the restoration of Job's health).

${ }^{6}$ The Qur'an: 21:83; 38:42-44; 4:163; 6:84; also see: Anthony H. Johns, "Three Stories of a Prophet: Al-Tabarī's Treatment of Job in Sūrah al-Anbiyā' 83-4 (Part I)," Journal of Qur'anic Studies 3 no.2 (2001), 39-61.
} 
However, the spring with miraculous healing powers resembles the protagonists' encounters with the Living Water in the stories of Na 'mān in the Hebrew Bible and Iskandar and Khidr in the Khamsa of Nizami.

\section{Stories of the Prophets (The Qisas al-Anbīyā') literature}

The stories of Abrahamic prophets such as Job were popular subjects in religious text and poetry and prose literature in the Islamic world. The story of Job was substantially developed in several texts and genres in the Islamic world, borrowing details from pre-Islamic sources such as the Book of Job, Rabbinic tales from the Talmud and the Midrash, and the Greek Testament of Job. Among several Islamic sources, Stories of the Prophets (the Qisas al-Anbīyā') literature stands out for the crucial role they played in developing the story of Job. The popularity of the story resulted in several branches of narratives in this genre and other Islamic texts. However, the narratives' multiplicity shared a core-the traditional story of Job in four stages mentioned earlier. Additionally, all of them included the Qur' anic mention of the miraculous spring. ${ }^{7}$
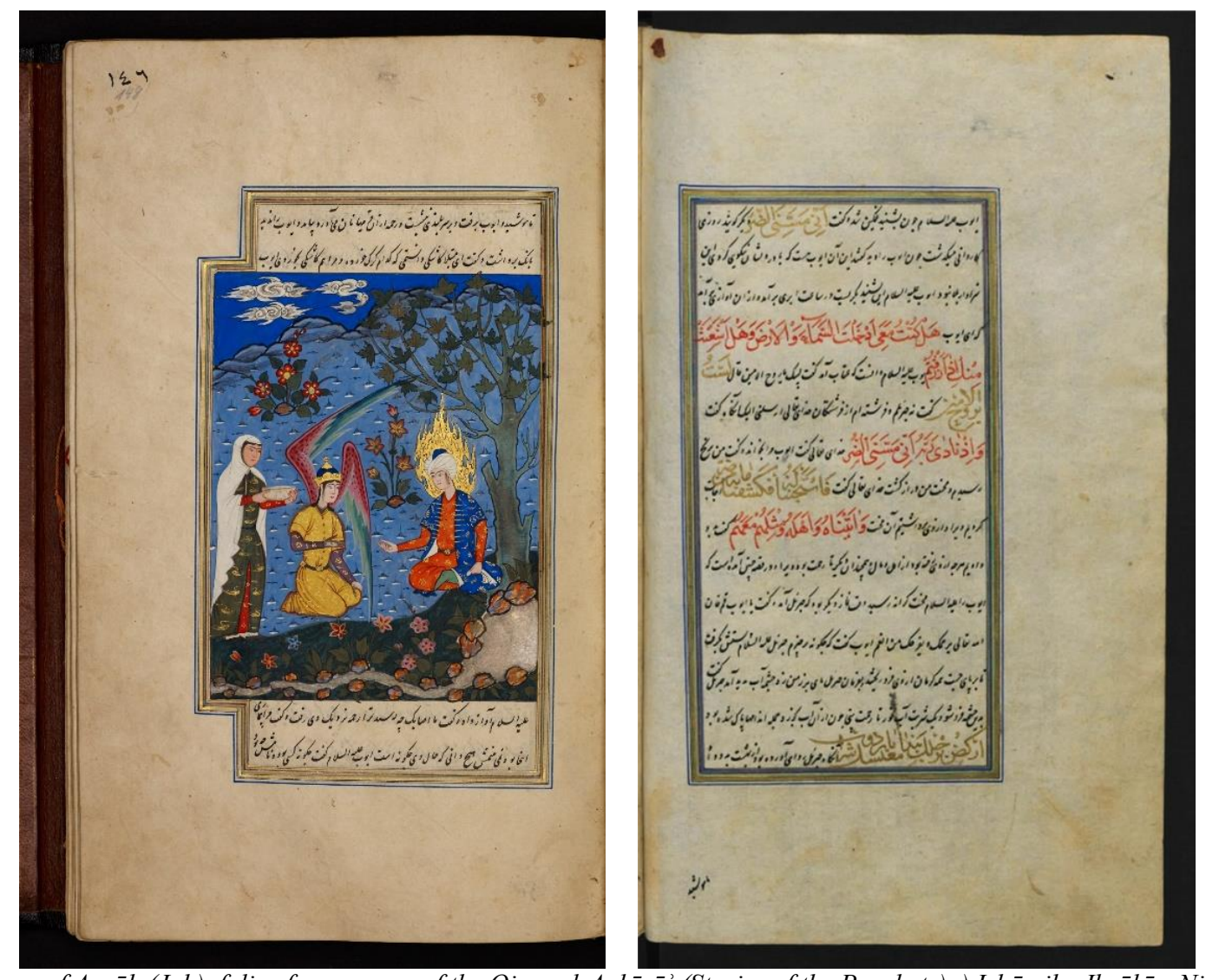

Recovery of Ayyūb (Job), folios from a copy of the Qisas al-Anbīyā' (Stories of the Prophets), ) Ishāq ibn Ibrāhīm Niyshābūrī, sixteenth c. Staatsbibliothek zu Berlin, Preußischer Kulturbesitz, Orientabteilung, Diez A fol. 3, f. 148r (left) and Diez A fol. 3 , fol. $147 v$ (right)

\footnotetext{
${ }^{7}$ Mohamad Reza Ghiasian, Lives of the Prophets, The Illustrations to Hafiz-i Abru's "Assembly of Chronicles" (London and Boston: Brill, 2018); Rachel Milstein, Karin Rührdanz, and Barbara Schmitz. Stories of the Prophets: Illustrated Manuscripts of Qișaș Al-Anbiyā' '(Costa Mesa, Calif: Mazda Publishers, 1998); Na'ama Brosh and Rachel Milstein, Biblical Stories in Islamic Painting (Jerusalem: Israel Museum, 1991); Tottoli, Biblical Prophets, 138-165.
} 
The 'Treatise on Silk-weaving' shares the narrative core of the traditional story of Job-four stages mentioned earlier - but focuses on its last stage: Job's restoration. First, the treatise summarizes the first three stages of the story of Job and arrives at the restoration of Job's health. Here, it relies on details developed in previous Islamic sources: God sends Gabriel to Job, who sought refuge in a cave. Gabriel struck the cave with his wings (shah-par), causing a miraculous spring to flow. Job washed diseases and worms away from his body and became young. Job's wife followed.

The treatise, however, departs from previous renditions of the story of Job at the end. Almost all other counterpart narratives give no details regarding Job's miraculous healing. In contrast, 'Treatise on Silk-weaving' introduces distinctive elements: while Job was floating in the sacred water, a piece of skin detached from his body and fell on the ground. As the treatise narrates: a white mulberry tree miraculously grew out of Job's peeled skin that had fallen on the ground. The worms which fell from Job's body climbed up, settled on the tree, and ate its leaves. They wrapped themselves in silk shrouds and died. Then, God sent Gabriel again to teach Job how to cultivate silk. Gabriel then taught Job how to boil the cocoons in the water while his wife reeled the silk. Gabriel also taught Job to throw the warp (chilli davāndan). The treatise then turns to silk-weaving. According to the treatise, no fewer than 83 of the prophets were silk weavers. It names Jethro (Shu'ayb), Moses (Mūsā), Aaron (Hārūn), Joshua (Yūsha'), David (Dāvūd), and Solomon (Suleiman). Each of these prophets wove different types of silk fabric. Finally, the treatise has a brief mention of the story of Abraham, who built the Ka'ba and wove its cover, the Kiswa. 
The treatise's addition to the story of Job includes details such as flesh-eating worms' transformation into silkworm caterpillars, the mulberry tree, silkworms feeding on the tree leaves, and silk cocoons. These elements exclusively appear in the silk-weaving treatise. The treatise expands this section of the story to add boiling and reeling cocoons, also crucial stages in producing silk yarns. This section in the story of Job addresses the primary steps in sericulture, reeling, and weaving silk. The treatise also locates Job in a line of silk-weaver prophets. In doing so, it bridges between the Abrahamic story of Job and the stages of sericulture in practice. Thus, the treatise composes an etiology of silk and informs the reader about how sacred the inception of sericulture was. These additions seemingly act as an addendum to the story's widely narrated form, most likely well-known and popular among the public in the late fifteenth and early sixteenth centuries. This odd alteration to the story of Job in fact support the sacred and religious status of the silk craft by adopting Job as the founder and patron-saint of sericulture and silkweaving.

\section{Job and worms}

This observation regarding the story of Job as the origin-story of sericulture and silk-weaving raises this question: why the silk-weaving treatise chose Job, and not another Abrahamic prophet, to apprise an origin-story for sericulture and silk-weaving? This paper suggests that the answer to this question lies in the association of Job with worms. The treatise had the difficult task of connecting two unrelated narratives: the traditional story of an Abrahamic prophet and sericulture. The latter is the process of producing silk yarns, which begins with rearing silkworms. Any prophet's account could potentially act as a sericulture's origin-story, but only if it mentioned silkworms. Unfortunately, silkworms feature in no prophets' stories. The 'Treatise on Silk-weaving' seems to have come up with an ingenious solution. Although the story of Job does not include silkworms, it characterizes flesh-eating worms. These worms emerge at the end of the story. This placing of flesh-eating worms in the story provided an opportunity to overlap with the silkworms at the beginning of the story of sericulture.

The treatise needed to resolve another dilemma: the traditional story of Job mentions flesh-eating worms, not silkworms. The treatise needed a transition between the two. The treatise's answer is to describe a metamorphosis: the flesh-eating worms fell from Job's body to let it heal, and in the processes became herbivorous silkworms. This miraculous transformation provides a refined transition from the traditional story of Job to the story of sericulture.

The treatise's narrative of worms in the story of Job was unprecedented. Although worms were featured in a few previous accounts of the story of Job, they did not have a central role until the 'Treatise of Silk-Weaving.' Furthermore, among Islamic sources, the Qur' an does not mention any worms in its narrative of Job. Similarly, a group of Islamic sources that included the story of Job did not mention any worms of any kind. Among them are prominent sources such as Stories of the Prophets (Qisas al-Anbīyâa $)$ by Kis $\bar{a} \overline{1}^{-}\left(8^{\text {th }}-9^{\text {th }}\right.$ c.), History of the Prophets and Kings (Tarīkh al-Rusul va al-Mulūk) by Tabarī $\left(9^{\text {th }}-10^{\text {th }} \mathrm{c}\right.$.), the Book of God (Ilāhī-Nāmi) by Attar $\left(12^{\text {th }}-13^{\text {th }}\right.$ c.), Bezels of Wisdom (Fusūs al-Hikam) by Ibn Arabi $\left(12^{\text {th }}-13^{\text {th }}\right.$ c.), the Beginning and the End (al-Bidāya ' wa al-Nihāya') by Ibn Kathīr $\left(14^{\text {th }}\right.$ c.), the Sultānī Collection of Histories (Majma' al-Tawārīkh-i Sultānī) by Hafiz Abrū $\left(15^{\text {th }}\right.$ c.). Such Islamic and pre-Islamic sources mention worms at all exclusively flesh-eating worms and only in the context of Job's affliction. 
A few examples are the Book of Job, Correct Tradition (Sahīh) by Bukhārī ( $9^{\text {th }} \mathrm{c}$.), Lives of the Prophets ('Ara' is al-Majālis fì Qisas al-Anbīyā') by Tha ālibī $\left(10^{\text {th }}-11^{\text {th }}\right.$ c.), Story of the Prophets (Qisas al-Anbīyā') by Mullā Muhammad Juviyrī (10 $10^{\text {th }} \mathrm{c}$.), Story of the Prophets (Qisas alAnbīyā') by Ishāq ibn Ibrāhīm Niyshābūrī (12 ${ }^{\text {th }}$ c.), Story of the Prophets (Qisas al-Anbīyā') by Rabghūzī $\left(13^{\text {th }}-14^{\text {th }}\right.$ c.), Story of the Prophets (Qisas al-Anbīyā') by Ibn Mutarrif al-Tarafī (16 ${ }^{\text {th }}$ $17^{\text {th }} \mathrm{c}$.), Complete History (al-Kāmil fi al-Tārîkh) by Ibn Athīr $\left(12^{\text {th }}-13^{\text {th }} \mathrm{c}\right.$.), and the Cream of Histories (Zubdat al-Tawārīkh) by 'Āshūrī (16 ${ }^{\text {th }} \mathrm{c}$.). Among the second group of sources, Rabghūzī's Stories of the Prophets provides the closest parallel to the silk-weaving treatise. Besides the treatise, Rabghūzî̀'s work is the only source that mentions a miraculous transformation of the worms during Job's restoration. In this source, flesh-eating worms fallen from Job's body turned into golden locusts and rained on him as a reward-a clear parallel to the 'Treatise of Silk-weaving' but with noticeable differences. Bukhari's Correct Tradition and Ibn Athīr's Complete History also mentions the golden locust rain. However, these two sources do not note any transformation of screwworms into golden locusts. Narratives such as Rabghūzī's probably inspired the treatise's author to include the flesh-eating worms' transformation but the silk-weaving treatise innovated in turning the flesh-eating worms into silkworms. ${ }^{8}$

\section{Job and the mulberry tree}

The miraculous presence of the mulberry tree is another crucial element of the story of Job in the silk-weaving treatise. However, whereas the worms had some precedent in the traditional story of Job, the mulberry tree is entirely novel. More importantly, the treatise left no doubts that the miraculous tree was a white mulberry tree (dirakht-i tūt-i sifìd). This specification of the tree species is vital to the story of Job's fusion with the origin-story of sericulture due to the essential role white mulberry tree leaves play in the silkworm's nursery.

The author of the 'Treatise on Silk-weaving' may have drawn inspiration for the mulberry tree from the depictions of trees in a group of late medieval and early modern Islamic illustrations of Job. These paintings are parts of manuscripts narrating the story of Job, including the works mentioned earlier. Among them, a popular scene was Job's bathing marking his health's restoration. A halo often identifies him in the form of a flame surrounding his head. Most of these illustrated manuscripts also added Gabriel and Job's wife to the image. Gabriel is always shown with wings. In a sub-group of these paintings, Job is naked from head to waist, standing in the middle of the miraculous spring's pond. Gabriel is offering Job a robe brought from the heavens. Job's bare chest shows his rib-bones, which signifies his weak and ill body. This set of paintings depicts Job a few moments before the miraculous recovery.

\footnotetext{
${ }^{8}$ al-Rabghuzi, The Stories of the Prophets Qisas al-Anbiya': an Eastern Turkish Version, ed. H.E. Boeschoten and J. O'Kane (Leiden: Brill, 2015); al-Bukhari, Mukhtașar Șaḥịh al-Bukhārī: al-musammá al-tajrīd al-ṣarīh li-aḥkām aljāmi ‘ al-ṣaḥ̄ḥ, ed. Muḥammad Mahdī Sharīf (Bayrūt, Lubnān: Dār al-Kutub al-Ilmīyah, 2007); Ibn al-`Arabī, The Bezels of Wisdom, ed. R. W. J. Austin (New York: Paulist Press, 1980); Ibn Mutarrif al-Tarafi, The stories of the Prophets, ed. Roberto Tottoli (Berlin: Klaus Schwarz Verlag, 2003); al-Kisa'i, Tales of the Prophets (Qisas alanbiya'), ed. Wheeler M. Thackston Jr (Chicago: Great Books of the Islamic World, Inc., 1997).
} 


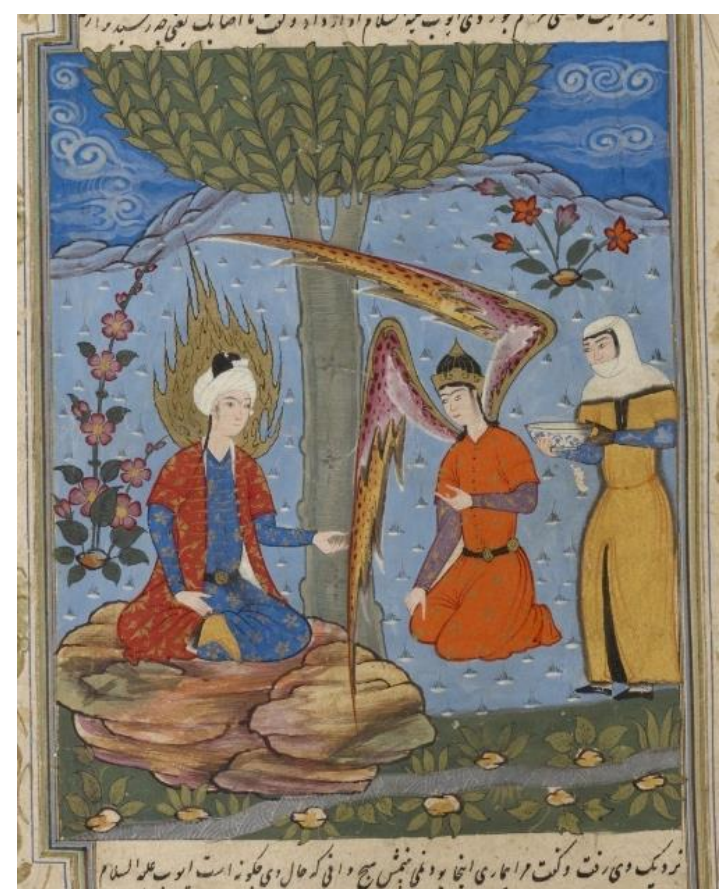

Recovery of Ayyūb (Job), Qișaș al-Anbiyā (Stories of the Prophets) by Niyshaburi, sixteenth c., New York Public Library, Spencer Collection (Pers. ms. 1), fol. 119r, cropped.

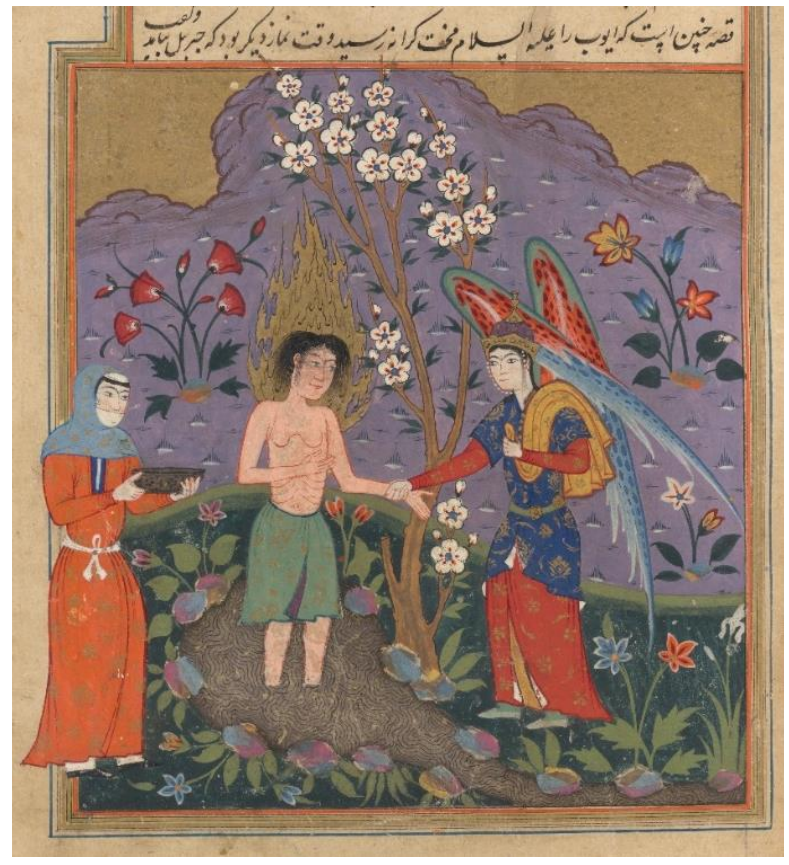

Recovery of Ayyūb (Job), Qiṣaș al-Anbiyā (Stories of the Prophets) by Niyshaburi, sixteenth $c$., New York Public Library, Spencer Collection (Pers. ms. 46), fol. 109r, cropped.

In another sub-group of these paintings of Job portraying trees, Job is already bathed, clothed, and recovered. He looks healthy and young, seated on higher ground in a conversation with Gabriel. In both sub-groups, Job's wife seems to arrive at the scene only a few moments earlier with a large bowl in her hands. Almost all these paintings depict a pond, a creek, or both. Worms are absent from these paintings.

Unlike worms, most of these paintings depict a tree at the edge of the pond. Nevertheless, the tree's presence in these paintings is a matter of aesthetics and representational style: trees by the ponds are common features in the period's several images with no fundamental role in their associated stories. Thus, there is not necessarily any connection between the trees depicted in the illustrations of the story of Job and the white mulberry tree mentioned in the treatise.

Nevertheless, these contemporary paintings might have inspired the author of the treatise to develop Job's sequel's story regarding its relevance to sericulture. These paintings were produced between the 1570s and 1590s, approximately four decades before completing the treatise in 1606. Thus, it is probable that the author of the treatise read the story of Job and saw its illustration in at least one of these or similar copies of the Qisas al-Anbīyā' (Stories of the Prophets).

\section{Weavers' social status in the Iranian society}

Job, consequently, makes sense as the patron-saint of weaving, but his association with sericulture indicates a rather high social status for silk crafts, which had not always been the case in Iran. Indeed, the change in the story of Job in the silk-weaving treatise reflects a quest for high socio-religious status in early modern Iran. It was probably a response to a broad prejudice against weavers in a group of pre-Safavid sources. In a futuwwatnāma composed in the late 
thirteenth century, the author included weavers (sing. jūla $)$ in a list of 12 types of people who could not receive the honor of the futuwwa. This futuwwatnäma accused weavers as morally flawed due to their actions or professions' inherent characteristics. In other examples, this list includes infidels and butchers since the former did not follow the true God and the latter took creatures' lives. The futuwwatnäma argues that weavers were incompatible with the futuwwa since they tended not to keep their oath. The categorization of weavers, infidels, and hypocrites under one group suggests that weaver's overall social status was low in this period. As another example from the seventh century, Ali ibn Abi Talib, the caliph of the Islamic world, called one of his appointees who turned against him, a son-of-a-weaver (ibn al-hä $i k$ ), and deposed him in a coarse letter. ${ }^{9}$

This distaste for weavers could not be further from the respect inherent in the 'Treatise on Silkweaving's' association of sericulture with Job. This social shift was rooted in the socio-economic dynamics of the late sixteenth century. The silk weaving treatise was written during the reign of the Safavid Shah Abbas I (r. 1588-1629), who substantially supported and promoted commercial infrastructure and expanded trade. As demonstrated in the works of Rudi Matthee, Willem Floor, and others, this period witnessed robust economic and commercial interactions between merchants, the Safavid state, and European trading companies, buying and selling mostly silk. ${ }^{10}$ Iran was a significant producer of silk for the global silk market between the fifteenth and seventeenth centuries. In addition to raw silk, many people in Isfahan, Kashan, and Yazd worked as silk-weavers and associated crafts. Thus, the treatise was written in the middle of a sustained silk boom. The social change that allowed the silk industry to claim Job as its patron must have happened sometime between the fourteenth and sixteenth centuries; however, the questions regarding its specifications remain to be contemplated.

This change in the story of Job has a global aspect to it as well. When buying silk from the Islamic world, European merchants paid mostly with silver taken from the New World. As a result, commodities moved westward while silver went east. In this sense, the Spanish conquest of the Americas provoked a mass production of silk in Iran to be sold and consumed in Europe.

\section{The butterfly effect}

A rare manuscript contains a unique version of the story of Job, focusing on worms and sericulture. This seemingly insignificant change in the story of Job sheds light on a social change in Safavid Iran in the global silk trade context. The treatise reflects silk-weavers' quest to reinforce social eminence in Safavid Iran. This social change was connected to the flow of silver from the New World to the early modern Islamic world. In this sense, the eastward movement of New World silver contributed to a change in the Safavid social structure and the story of Job in the Middle East in the interconnected early modern world. And in this way, the suffering of Job was transferred into precious silk, silver, and social capital for silk weavers in early modern Iran. Rabghūzī and his golden locusts were not so far from the truth after all.

\footnotetext{
${ }^{9}$ Wilferd Madelung, The Succession to Muhammad: A Study of the Early Caliphate (Cambridge, UK: Cambridge University Press, 1997), 165.

${ }^{10}$ Rudolph Matthee, The Politics of Trade in Safavid Iran: Silk for Silver, 1600-1730 (Cambridge, UK: Cambridge University Press, 1999); Willem Floor and Patrick Clawson, "Safavid Iran's Search for Silver and Gold," International Journal of Middle East Studies 32, no. 3 (2000): 345-368.
} 


\section{References}

"Risāli-yi Sha rbāfī va Giriftan-i Qabzi-yi Mākū," The Iranian Parliament Libraries, Museum, and Archives.

Afshari, Mehran and Mahdi Madayeni. Chāhārdah Riāli dar Bāb-i Futuwwat va Asnāf. Tehran: Chishmi, 1385/2006.

Afshari, Mehran. S̄̄ Futuwwat-nāmi-yi Dīgar, S̄̄ Risāli-yi Nāshinākhti dar Futuwwat va Pīshivarī va Qalandarī. Tehran Chishmi, 1391/2012.

al-Bukhari, Mukhtaṣar Șahīh al-Bukhārī: al-musammá al-tajrīd al-ṣarīh li-ahkām al-jāmi ‘ alșahīh. Translated and edited by Muḥammad Mahdī Sharīf. Beirut: Dār al-Kutub al-Ilmīyah, 2007.

al-Kisa'i, Tales of the Prophets (Qisas al-anbiya'). Translated and edited by Wheeler M. Thackston Jr. Chicago: Great Books of the Islamic World, Inc., 1997.

al-Rabghuzi, The Stories of the Prophets Qisas al-Anbiya: an Eastern Turkish Version. Translated and edited by H.E. Boeschoten and J. O'Kane. Leiden: Brill, 2015.

Brosh, Na'ama and Rachel Milstein. Biblical Stories in Islamic Painting. Jerusalem: Israel Museum, 1991.

Cahen, Claude, and Franz Taeschner. "Futuwwa." In the Encyclopaedia of Islam. Vol. 2 (C-G), edited by B. Lewis, Ch. Pellat, and J. Schacht, 961-969. Leiden: Brill, 1991.

Floor, Willem, and Patrick Clawson. "Safavid Iran's Search for Silver and Gold." International Journal of Middle East Studies 32, no. 3 (2000), 345-368.

Floor, Willem. "Fotovvat va Asnaf." Review of Chāhārdah Riāli dar Bāb-i Futuwwat va Asnāf, edited by Mehran Afshari and Mehdi Madayeni. Iranian Studies 37, no. 2 (2004): 366-368.

Floor, Willem. "Guilds and futuvvat in Iran." In Zeitschrift der Deutschen Morgenländischen Gesellschaft 134, no. 1 (1984): 106-114.

Floor, Willem. "The Guilds in Iran - an Overview from the Earliest Beginnings till 1972." In Zeitschrift der Deutschen Morgenländischen Gesellschaft 125, no. 1 (1975): 99-116.

Gevorgyan, Khachik. "Futuwwa Varieties and the Futuwwat-nama Literature: An Attempt to Classify Futuwwa and Persian Futuwwat-namas." British Journal of Middle Eastern Studies 40, no.1 (2013): 2-13.

Ghiasian, Mohamad Reza. Lives of the Prophets, The Illustrations to Hafiz-i Abru's “Assembly of Chronicles". London and Boston: Brill, 2018.

Ibn al-'Arabī. The Bezels of Wisdom. Translated and edited by R. W. J. Austin. New York: Paulist Press, 1980.

Ibn Mutarrif al-Tarafi. The stories of the Prophets. Translated and edited by Roberto Tottoli. Berlin: Klaus Schwarz Verlag, 2003.

Johns, Anthony H. "Three Stories of a Prophet: Al-Ṭabarī's Treatment of Job in Sūrah al-Anbiyā' 83-4 (Part I)." Journal of Qur'anic Studies 3, no.2 (2001): 39-61.

Keyvani, Mehdi. Artisans and Guild Life in the Later Safavid Period, Constructions to the Social-economic History of Persia. Berlin: Klaus Schwarz, 1982.

Madelung, Wilferd. The Succession to Muhammad: A Study of the Early Caliphate. Cambridge, UK: Cambridge University Press, 1997.

Matthee, Rudolph. The Politics of Trade in Safavid Iran: Silk for Silver, 1600-1730. Cambridge, UK: Cambridge University Press, 1999.

Milstein, Rachel, Karin Rührdanz, and Barbara Schmitz. Stories of the Prophets: Illustrated Manuscripts of Qiṣaș Al-Anbiyā'. Costa Mesa, Calif: Mazda Publishers, 1998. 
Nafisi, Said. "Futuwwatnami-i az Qarn-i Haftum-i Hijri”. Farhang-i Iran Zamin 10 (1962/1341): 225-281.

Newsom, Carol A. "Plural Versions and the Challenge of Narrative Coherence in the Story of Job." In The Oxford Handbook of Biblical Narrative, edited by Danna Nolan Fewell, 236244. New York: Oxford University Press: 2016.

Niyshābūrī, Ishāq ibn Ibrāhīm. Qisas al-Anbīyā' (Dāstān-hāyi Payāmbarān), ed. Habib Yaghmai. Tehran: Intesharat-I Ilmi va Farhangi, 2003/1382.

Tottoli, Roberto. Biblical Prophets in the Qur'an and Muslim Literature. New York: Routldge, 2002.

Zanier, Claudio. "Silk Cultivation in Italy, Medieval and Early Modern," Journal of Medieval Worlds 1, no. 4 (Winter 2019): 40-44.

Zanier, Claudio. Miti e culti della seta. Dalla Cina all'Europa. Padova: Universita`di Padova, CLEUP, 2019.

Zarkoub, Najm al-Din. "Futuwwatnama." In Rasā'l-i Javānmardān, Mushtamil bar Haft Futuvvatnämi, edited by Morteza Sarraf, 167-218. Tehran and Paris: Departement d'Iranologie de L'Institut Franco-Iranien de Recherche, Mo'in Publishing House, and Librairie d'Amerique et d'Orient Adrien-Maisonneuve, 1973/1352. 